\title{
Das Cautelares à Estabilização da Tutela Antecipada Contra Fazenda Pública: Um Tributo a Calmon de Passos
}

\author{
From Precautionary Measures to Stabilization of Injunctive Relief Against the Public Treasure: \\ A Tribute to Calmon Passos
}

\author{
Sandoval Alves da Silva' \\ Marcelene Dias da Paz Veloso \\ João Renato Rodrigues Siqueira' \\ 'Universidade Federal do Pará - UFPA, Brasill
}

\section{Resumo}

O presente artigo apresenta a evolução da teoria das cautelares, começando pelo estudo baseado na doutrina de Calmon de Passos e indo até a estabilização dos efeitos da tutela provisória de urgência satisfativa, mecanismo processual inovador, instituído pelo Código de Processo Civil. Busca-se demonstrar a correlação da teoria cautelar e da aplicabilidade da estabilização dos efeitos da tutela provisória de urgência requerida em caráter antecedente contra a Fazenda Pública como um instrumento processual de efetivação dos direitos sociais no campo do direito material. Partindo da análise da Fazenda Pública e de suas prerrogativas, passando pelo exame da teoria das cautelares até a tutela provisória no Código de Processo Civil, conclui-se pela aplicabilidade do instituto da estabilização da tutela provisória de urgência requerida em caráter antecedente contra a Fazenda Pública.

Palavras-chave: Processo civil; Cautelares; Tutela provisória; Estabilização, Fazenda pública

\begin{abstract}
This paper introduces a study on the development of the precautionary theory issued by Calmon de Passos until the stabilization of the effects of provisional protection of satisfactory urgency, an innovative procedural mechanism, instituted by the Code of Civil Procedure. The key purpose of the paper is to testify to the interrelationship of precautionary theory and the applicability of the stabilization of the effects of provisional urgent protection required in an antecedent character against the Public Finance as a procedural instrument for the enforcement of the social rights in the field of material law. It addresses the Public Finance and its prerogatives. Immediately thereafter, it addresses the theory the precautionary theory until provisional protection in the Civil Procedure Code and the stabilization of the effects of the precautionary measures. Finally, the applicability of

the institute for the stabilization of provisional emergency relief required in an antecedent character against the Public Finance is maintained.
\end{abstract}

Keywords: Civil procedure; Precautionary measures; Injunctive Relief; Stabilization; Public finance

\section{Introdução}

Foi com muita honra que se atendeu ao convite formulado pela Associação Norte e Nordeste de Professores de Processo (ANNEP) para participar como um dos palestrantes no Congresso Centenário J. J. Calmon de Passos, ocorrido por videoconferência nos dias 9, 10 e 11 de julho de 2020. A exposição versou sobre "a estabilização dos efeitos da tutela provisória de urgência antecipada concedida em caráter antecedente nas ações contra a Fazenda Pública” no Painel "Tutela provisória”"

1 O interesse pelo tema da estabilização dos efeitos da tutela de urgência antecipada antecedente vem da orientação de um trabalho de conclusão de curso de graduação, que culminou em um artigo que está para ser publicado na edição n. ${ }^{\circ}$ 111 da Revista Brasileira de Direito Processual (RBDPro) sob o título: "A estabilização dos efeitos da tutela antecipada contra 
O desafio de muita honra trouxe a possibilidade de dialogar com os ensinamentos do Emérito Professor J. J. Calmon de Passos acerca das tutelas cautelares, já bem antes do atual sistema de provisoriedade da tutela jurisdicional, positivado no Código de Processo Civil (CPC) vigente (Lei n.․ㅡ 13.105, de 16 de março de 2015), Calmon de Passos anunciava premissas que explicam epistemologicamente os fenômenos de hoje, porém com roupagem e nomes não ventilados à época por mera casualidade temporal, pois na essência a definição continuaria a explicar os institutos da tutela provisória.

O presente artigo busca, em um primeiro momento, demonstrar a conexão entre as definições de Calmon de Passos para enquadrar a tutela antecipada e, posteriormente, descolado das ideias do ilustre professor, defende a estabilização dos efeitos concedidos em sede de tutela antecipada antecedente contra a Fazenda Pública. A correlação do tema da tutela provisória com a estabilização dos efeitos provém de uma orientação de trabalho de conclusão de curso na Universidade Federal do Pará.

Dentre as várias inovações trazidas pelo CPC, destacam-se, para os fins do presente artigo, a unificação da tutela provisória e a possibilidade de estabilização dos efeitos da tutela antecipada concedida em caráter antecedente, isto é, antes mesmo da efetiva entrega definitiva da tutela jurisdicional. Adiscussão aqui pretendida vai um pouco mais além para alcançar a aplicação do fenômeno da estabilização contra a Fazenda Pública, apesar da existência de vários óbices a esse objetivo, em especial, as prerrogativas da Fazenda Pública, que incluem até a vedação de concessão de tutela antecipada e cautelar, conforme hipóteses da Lei n.o 8.437, de 30 de junho de 1992, e da Lei n.o 9.494, de 10 de setembro de 1997, por exemplo.

Considerando essas ponderações, abordar-se-ão as prerrogativas do ente público designado pelo termo "Fazenda Pública", os efeitos no acesso à justiça decorrente da unificação das espécies de tutela provisória, a adaptação do pensamento de Calmon de Passos sobre tutelas cautelares, antes de examinar a regulação do CPC de 2015, para posteriormente adentrar o fenômeno da estabilização dos efeitos da tutela antecipada antecedente e sua aplicação contra a Fazenda Pública, em especial para garantir a efetividade dos direitos humanos.

\section{A Fazenda Pública e suas prerrogativas}

Cabe inicialmente esclarecer que, processualmente, o termo "Fazenda Pública" designa o Ente Público em juízo acompanhado de determinadas prerrogativas processuais. Por outras palavras, é a expressão utilizada para qualificar as pessoas jurídicas de direito público envolvidas em ações judiciais², que abrangem a administração pública, direta ou indireta, por meio de autarquias ou de fundações públicas, quando se encontra como sujeito processual³.

As normas que regem a Fazenda Pública, especialmente as vantagens processuais que lhe oferece o ordenamento jurídico, podem representar obstáculos à estabilização dos efeitos da tutela provisória que serve como instrumento processual na redução do excesso de demandas envolvendo o Poder Público com o oferecimento de soluções céleres e eficazes.

De acordo com as premissas acadêmicas e profissionais de um passado recente, o interesse público é indisponível, mas isso tem mudado gradativamente ${ }^{4}$, o que justificaria um tratamento processual distinto para a Fazenda Pública, se consideradas as normas processuais usuais aplicadas às ações de direito privado ${ }^{5}$. Nesse sentido, podem-se citar várias prerrogativas, como a dilação de prazos (na forma

a Fazenda Pública como instrumento de efetivação dos direitos sociais”. Esse assunto será aprofundado no presente artigo com as considerações de Calmon de Passos.

2 CUNHA, Leonardo Carneiro da. A Fazenda Pública em juízo. 14. ed. Rio de Janeiro: Forense, 2017, p. 1-2.

3 MEIRELleS, 1998, p. 590, apud CUNHA, Leonardo Carneiro da. A Fazenda Pública em juízo. 14. ed. Rio de Janeiro: Forense, 2017, p. 1.

4 Para uma detida análise de questão, consultar: SILVA, Sandoval Alves da. O Ministério Público e a concretização dos direitos humanos. Salvador: JusPodivm, 2016a, p. 218-226; VENTURI, Elton. Transação de direitos indisponíveis? Revista de Processo, São Paulo, v. 41, n. 251, p. 391-426, jan. 2016.

5 BUENO, Cassio Scarpinella. O poder público em juízo: uma proposta de sistematização. Palestra proferida na IV Jornada de Direito Processual Civil. Fortaleza, 2001, p. 7. 
no artigo 183 do CPC), a intimação pessoal do advogado público, o procedimento especial de pagamento de débitos mediante precatórios, a remessa necessária (artigo 496 do CPC), a vedação à concessão de liminares contra a Fazenda Pública (artigo 100 da Constituição de 1988) etc.

O precatório judicial é o regime de cumprimento de provimentos judiciais e títulos extrajudiciais para pagamento de débitos com base no orçamento público, o qual consiste em uma ordem de inclusão do valor devido na sua fila de pagamento. O precatório judicial surgiu historicamente de privilégios da nobreza portuguesa ${ }^{6}$ e atualmente se justifica pela necessidade de viabilizar o adimplemento de obrigação pecuniária sem prejuízo às atividades essenciais do Estado ${ }^{7}$.

O reexame necessário, que tem origem romano-canônica e passa pelo direito português e brasileiro $^{8}$, consiste na atuação ex officio do magistrado que remete os autos ao tribunal em decisões contrárias à Fazenda Pública, o que faz com que a sentença só produza efeitos se vier a ser confirmada pelo tribunal ${ }^{9}$. Por outras palavras, o reexame almeja a reanálise obrigatória da sentença de primeiro grau pelo Tribunal a que estiver vinculado, que se posiciona contrariamente ao interesse público, configurando verdadeira condição de eficácia da sentença ${ }^{10}$.

Para o presente artigo, importa destacar a dispensa da remessa necessária prevista no artigo 496 do CPC de 2015 por fundamento econômico, precedentes ou teses e por orientação administrativa, visto que nesses casos pode-se ventilar a estabilização dos efeitos da tutela antecipada antecedente. Dentre essas hipóteses, destacam-se: a) as condenações equivalentes a valores inferiores a 1000 (mil), 500 (quinhentos) e 100 (cem) salários-mínimos para a União, Estados (incluindo o Distrito Federal) e Municípios, respectivamente; b) o provimento judicial fundado em entendimento sumulado e em acórdãos proferidos pelos tribunais superiores, bem como o entendimento firmado em incidente de resolução de demandas repetitivas ou de assunção de competência; c) a orientação vinculante administrativa consolidada em manifestação, parecer ou súmula administrativa ${ }^{11}$.

Outro viés importante provém das exceções colacionadas às limitações de liminares contra a Fazenda Pública. Tais limitações consolidaram-se no julgamento da Ação Declaratória de

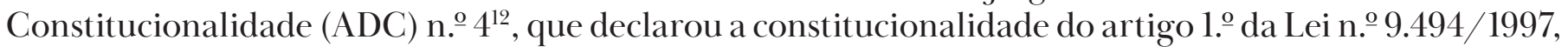
reconhecendo limites e vedações à concessão de tutela antecipada contra a Fazenda Pública, em virtude da preocupação em preservá-la contra o deferimento epidêmico de tutelas antecipatórias sem a observância do contraditório e da ampla defesa ${ }^{13}$.

A partir dessa atuação legislativa confirmada pelo Supremo Tribunal Federal (STF), ficou assentado o entendimento definitivo de que não cabe a concessão de liminar contra a Fazenda Pública nos seguintes casos: a) quando esse procedimento tiver por finalidade a reclassificação ou a equiparação de servidores públicos, bem como a concessão de aumento ou a extensão de vantagens, hipótese na qual

$6 \quad$ SILVA, Marcus Vinicius Fernandes Andrade. Precatórios judiciais e requisições de pequeno valor: algumas considerações. Âmbito Jurídico, Rio Grande, ano XIII, n. 74, mar. 2010. Disponível em: http://www.ambito-juridico.com. br /site/index.php?n_link=revista_artigos_leitura\&artigo_id=7286. Acesso em: 12 nov. 2018.

$7 \quad$ RISSO, Edimara Sachet; BUZETTI, Jorge Augusto. A possibilidade de deferimento da tutela antecipada em face da Fazenda Pública. Revista Faz Ciência, [s.l.], v. 11, n. 14, jul./dez. 2009, p. 19.

8 SCALABRIN, Felipe; SANTANNA, Gustavo. Perfil da remessa necessária no novo Código de Processo Civil. Revista da AJURIS, Porto Alegre, v. 42, n. 137, mar. 2015, p. 305.

9 CÂMARA, Alexandre Freitas. O novo processo civil brasileiro. 3. ed. São Paulo: Atlas, 2017, p. 261.

10 SCALABRIN, Felipe; SANTANNA, Gustavo. Perfil da remessa necessária no novo Código de Processo Civil. Revista da AJURIS, Porto Alegre, v. 42, n. 137, mar. 2015, p. 304.

11 SILVA, Sandoval Alves da; SILVA, Barbie Chaves. A estabilização dos efeitos da tutela antecipada contra a Fazenda Pública como instrumento de efetivação dos direitos sociais. Revista Brasileira de Direito Processual, Belo Horizonte, ano 28, n. 111, [jul./set. 2020]. No prelo.

12 Supremo Tribunal Federal (Pleno). Ação Declaratória de Constitucionalidade 4 Distrito Federal. Relator: Min. Sydney Sanches. Relator do acórdão: Min. Celso de Mello. Julgado: 1 out. 2008. DJe, Brasília, DF, n. 213, 30 out. 2014.

13 Supremo Tribunal Federal (2. turma). Ag. Reg. na Reclamação 8.335 Piauí. Relator: Min. Ricardo Lewandowski. Julgado: 19 ago. 2014. DJe, Brasília, DF, n. 167, 29 ago. 2014. 
também não cabe a execução provisória da sentença ${ }^{14}$; b) para a compensação de créditos tributários, a entrega de mercadorias e bens oriundos do exterior, a reclassificação ou a equiparação de servidores públicos e a concessão de aumento ou a extensão de vantagens ou o pagamento de qualquer natureza ${ }^{15}$; c) nas ações e nos procedimentos de natureza cautelar ou preventiva ${ }^{16}$.

Como se sabe, as prerrogativas processuais concedidas à Fazenda Pública sustentam-se em virtude da necessidade de equilibrar a relação processual, com fundamento, supostamente, no princípio da supremacia do interesse público sobre o interesse privado e no princípio da indisponibilidade do interesse público, que norteiam todos os atos pertinentes ao Poder Público ${ }^{17}$. Porém, há várias hipóteses em que se pode aplicar a concessão de liminares contra a Fazenda Pública e sua estabilização, consoante já se anuncia.

\section{Das tutelas cautelares à luz de Calmon de Passos à tutela provisória no Código de Processo Civil}

Calmon de Passos apresenta um profundo estudo das ações cautelares à luz do CPC de 1973, fazendo uma contextualização do tema na Teoria Geral do Direito, na Teoria Geral do Processo, chegando à Teoria Geral do Processo da Cautelar, de forma a conhecer o conjunto e a unidade, deduzindo os princípios e construindo a harmonia e a coerência sistêmica do instituto cautelar ${ }^{18}$.

A teoria geral tem assento em três fenômenos jurídicos que são indissociáveis: a liberdade, a sociabilidade e o sistema de necessidades, isso tudo relacionado com a insuficiência de bens que os satisfaçam. Não serão abordadas as situações-obstáculos (pretensões resistidas), aborda-se o direito, como modo prático de distribuição dos bens da vida de duas formas: ou de forma voluntária, ou por meio da utilização do processo e do exercício do direito de ação e do poder-dever jurisdicional do Estado, caracterizado tal poder-dever especialmente pela substitutividade (dos sujeitos envolvidos no conflito), por gerar norma individualizada proveniente de um sujeito estranho à relação material ${ }^{19}$.

A tutela jurídica por meio da jurisdição pode ser: a) reparatória, quando busca a remoção da situação-obstáculo; b) preventiva, quando se opõe à situação-obstáculo totalmente caracterizada, por ser certa ou muito provável; c) integrativa, quando remove a situação-obstáculo impeditiva da produção de efeitos jurídicos, por ato de declaração de vontade que integrará o direito a partir da decisão do juízo. Aqui, como o foco é a tutela preventiva, enfatizar-se-á a segunda espécie de tutela jurídica-jurisdicional.

A tutela preventiva pode ser substancial ou processual. A tutela substancial ou de direito material destina-se à pretensão à segurança de um direito, um bem ou uma situação jurídica, que está sob risco ou perigo. Nesse caso, pretende-se resguardar do risco de futura lesão o bem da vida já atribuído a

14 Lei n.. 12.016/2009, art. 14, § 3..: "A sentença que conceder o mandado de segurança pode ser executada provisoriamente, salvo nos casos em que for vedada a concessão da medida liminar".

15 Lei n. ${ }^{\circ} 12.016 / 09$, art. 7. ․ㅗ $\$$ 2. . : "Não será concedida medida liminar que tenha por objeto a compensação de créditos tributários, a entrega de mercadorias e bens provenientes do exterior, a reclassificação ou equiparação de servidores públicos e a concessão de aumento ou a extensão de vantagens ou pagamento de qualquer natureza”.

16 Lei n. . 8.437/1992, art. 1.․ "Não será cabível medida liminar contra atos do Poder Público, no procedimento cautelar ou em quaisquer outras ações de natureza cautelar ou preventiva, toda vez que providência semelhante não puder ser concedida em ações de mandado de segurança, em virtude de vedação legal. § 1. ํㅜo será cabível, no juízo de primeiro grau, medida cautelar inominada ou a sua liminar, quando impugnado ato de autoridade sujeita, na via de mandado de segurança, à competência originária de tribunal. §2.․ O disposto no parágrafo anterior não se aplica aos processos de ação popular e de ação civil pública. § 3. aão será cabível medida liminar que esgote, no todo ou em qualquer parte, o objeto da ação. $\$ 4 .^{\circ}$ Nos casos em que cabível medida liminar, sem prejuízo da comunicação ao dirigente do órgão ou entidade, o respectivo representante judicial dela será imediatamente intimado. $\$ 5 .^{\circ}$ Não será cabível medida liminar que defira compensação de créditos tributários ou previdenciários".

17 DIAS, Licínia Rossi Correia. Direito administrativo I. São Paulo: Saraiva, 2012. (Saberes do Direito, 31).

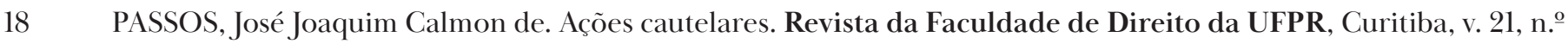
0, 1983, p. 29-30. Disponível em: https:/ / revistas.ufpr.br/direito/article/view/8872/6185. Acesso: 9 jul. 2020.

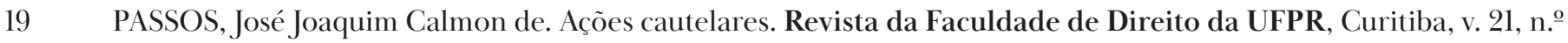
0, 1983, p. 30-31. Disponível em: https:/ / revistas.ufpr.br/direito/article/view/8872/6185. Acesso: 9 jul. 2020. 
alguém, antecipar a atribuição do bem da vida que seria futuramente devido e constituir as condições necessárias para assegurar a atribuição futura do bem da vida, se ele vier a ser devido. Já a tutela preventiva processual funda-se em prescrições de direito processual, mas vinculadas ao direito material; visa de forma mediata à proteção da tutela jurisdicional, como o provável direito da parte, e de modo imediato, à efetividade de sentença futura e certa ${ }^{20}$. Cabe destacar que o processo cautelar, seja de cognição, seja de execução, é processo a serviço do processo, não visa à proteção do direito material.

A tutela preventiva substancial satisfaz à pretensão material e exaure-se em si mesma e se a tutela preventiva for conexa com outra pretensão material isso é resultado da vinculação das relações jurídicas substanciais; já a tutela processual é apenas instrumental, não é satisfativa, mas está sempre relacionada a um processo que buscará resultado útil ${ }^{21}$.

Verificou-se que há uma diferença entre a tutela preventiva - que visa à proteção do direito material e que protege o bem da vida, mediante a certificação da existência de uma situação de perigo e a pretensão de direito processual - que visa à efetividade da futura tutela de um direito controvertido, quando a demora da tutela põe em perigo e ameaça a eficácia, parcial ou total, da sentença que a efetivará. A tutela substancial é manejada, por meio de ação de conhecimento ou execução, atendidos os seus pressupostos, enquanto a tutela preventiva processual efetiva-se com o processo cautelar e seus pressupostos específicos ${ }^{22}$.

Vê-se que, para Calmon, é importante destacar a diferença entre a pretensão à segurança substancial, de caráter satisfativo, e uma pretensão processual à segurança, de caráter instrumental, essa denominada "pretensão cautelar", realizada por ações cautelares. A pretensão substancial à segurança é exercitada mediante as ações, processos e procedimentos estabelecidos em lei para todas as pretensões de direito material: ações de conhecimento e de execução em seu modo típico de atuar²3.

Porém, há várias hipóteses de tutela reparatória protegidas pelo procedimento cautelar. Não seria possível reuni-las em uma só categoria jurídica por serem inconciliáveis e não fazerem parte de uma mesma teoria geral. Caso todas fizessem parte da tutela preventiva, então todas seriam espécie de pretensão à segurança, o que não é verdade, já que a pretensão substancial à segurança é submetida aos princípios da teoria geral do processo de conhecimento e de execução, atendidos os seus pressupostos, enquanto a pretensão processual à segurança possui teoria própria, que não é atinente ao processo de conhecimento e de execução ${ }^{24}$, mas sim à teoria da tutela provisória ou preventiva.

No CPC de 1939, que serve para contextualizar várias questões referentes ao tema, o legislador estabeleceu medidas tipicamente cautelares, que asseguram o resultado do processo, sem adentrar o campo do direito material (sequestro e arresto). No mesmo livro, tipificou medidas que visam assegurar o direito substancial, sem relevância processual (cauções negociais), e outras ainda, sem caráter jurisdicional (protesto de título). Por fim, outras medidas estabelecem o dever que o juiz tem de prover no processo o bom andamento, sobre coisas e pessoas que ajudem a formar seu convencimento, ou o dever de prover interesse do ordenamento jurídico sob tutela jurisdicional (obras em coisa litigiosa, guarda de filhos). Assim, deve-se separar o que é essencialmente cautelar do que é procedimentalmente cautelar, afastando as prescrições típicas das cautelares daquelas que não o são ${ }^{25}$.

20 PASSOS, José Joaquim Calmon de. Ações cautelares. Revista da Faculdade de Direito da UFPR, Curitiba, v. 21, n. ${ }^{\circ}$ 0, 1983, p. 32-33. Disponível em: https://revistas.ufpr.br/direito/article/view/8872/6185. Acesso: 9 jul. 2020.

21 PASSOS, José Joaquim Calmon de. Ações cautelares. Revista da Faculdade de Direito da UFPR, Curitiba, v. 21, n.o 0, 1983, p. 34. Disponível em: https:/ / revistas.ufpr.br/direito/article/view/8872/6185. Acesso: 9 jul. 2020.

22 PASSOS, José Joaquim Calmon de. Ações cautelares. Revista da Faculdade de Direito da UFPR, Curitiba, v. 21, n.ํㅗ 0, 1983, p. 34. Disponível em: https:/ / revistas.ufpr.br/direito/article/view/8872/6185. Acesso: 9 jul. 2020.

23 PASSOS, José Joaquim Calmon de. Ações cautelares. Revista da Faculdade de Direito da UFPR, Curitiba, v. 21, n. ${ }^{\circ}$ 0, 1983, p. 40. Disponível em: https:/ / revistas.ufpr.br/direito/article/view/8872/6185. Acesso: 9 jul. 2020.

24 PASSOS, José Joaquim Calmon de. Ações cautelares. Revista da Faculdade de Direito da UFPR, Curitiba, v. 21, n. ${ }^{\circ}$ 0, 1983, p. 42. Disponível em: https:/ / revistas.ufpr.br/direito/article/view/8872/6185. Acesso: 9 jul. 2020.

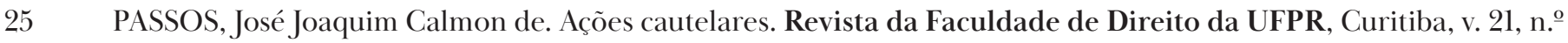
0, 1983, p. 44-45. Disponível em: https://revistas.ufpr.br/direito/article/view/8872/6185. Acesso: 9 jul. 2020. 
Enfim, as situações-obstáculos podem ser eliminadas pelo Estado-juiz por meio de prestação da tutela jurídica que pode ser reparatória, integrativa e preventiva. A reparatória cumpre-se por meio da certificação do direito por declaração, declaração com eficácia condenatória ou com eficácia executória, ou exercício da pretensão executória. A integrativa efetiva-se por meio da declaratória com eficácia constitutiva. A preventiva efetiva-se por qualquer meio e diversifica-se em função do bem da vida. Há ainda a tutela preventiva, que é substancial e assegura o bem da vida, e a processual, que dá ao processo a segurança e um resultado útili ${ }^{26}$.

Portanto, devem-se distinguir as medidas essencialmente cautelares - que se vinculam instrumentalmente a um processo -, as medidas provisionais - que visam o regular andamento do processo ou seu resultado eficaz - e as medidas só procedimentalmente cautelares ou topologicamente cautelares - que se relacionam a interesses de natureza substancial, sem um necessário caráter instrumental ${ }^{27}$.

As concepções apresentadas por Calmon de Passos servem para entender toda a fenomenologia atual do CPC de 2015, em que pese a unificação, visto que ainda persistem medidas essencialmente cautelares, antecipatórias dos efeitos da tutela definitiva e tutelas reparatórias que podem ser protegidas pelo rito célere da tutela provisória prevista nos artigos 294 a 311 do CPC, razão pela qual, saindo dos ensinamentos do mestre baiano, penetra-se nas concepções atuais trazidas pela doutrina.

Como se percebe, a tutela preventiva ou provisória, em especial, a antecipação provisória dos efeitos da tutela definitiva, não requer cognição exauriente, bastando a sumária. A principal finalidade da tutela antecipada antecedente é redistribuir o ônus do tempo no processo, antecipando a satisfação ou assegurando o direito. A tutela provisória, ao contrário da tutela definitiva, permite a efetivação ou a proteção de um direito por meio da análise superficial dos fatos, em precariedade, pois sua eficácia restringe-se à duração do processo, podendo ser revogada ou modificada a qualquer momento, não sendo atingida pelo fenômeno da coisa julgada ${ }^{28}$.

A tutela definitiva, ao contrário, requer tempo, visto que a cognição exauriente diz respeito ao conhecimento detalhado do litígio ou do problema, para que a decisão esteja fundamentada em um juízo de certeza. A demora é elemento essencial para o esgotamento dos mecanismos processuais necessários à formação do entendimento do juízo, inclusive com o exercício do contraditório pleno, porém há situações em que o tempo necessário à cognição exauriente pode colocar em risco a efetividade da tutela ou torna-se um fardo a ser suportado pelo titular do direito ${ }^{29}$.

Anteriormente, à luz do CPC de 1973 (Lei n.o 5.869, de 11 de janeiro de 1973), acreditava-se que o procedimento ordinário, equivalente ao atual procedimento comum, era suficientemente apto a proporcionar efetividade às diversas situações apresentadas ao Judiciário, de modo que o processo cautelar era utilizado como alternativa na busca de uma tutela jurídica adequada, passando a ser manuseado como meio para alcançar a concessão dos efeitos de uma tutela antecipadamente ${ }^{30}$.

Observa-se, então, uma verdadeira confusão no processo cautelar, conforme busca explicar Calmon de Passos $^{31}$, visto que ele não se fazia suficiente para que fosse exaurida a pretensão de um direito, a fim de afastar a necessidade da propositura de uma ação principal, porque uma decisão

26 PASSOS, José Joaquim Calmon de. Ações cautelares. Revista da Faculdade de Direito da UFPR, Curitiba, v. 21, n. ${ }^{\circ}$ 0, 1983, p. 47. Disponível em: https://revistas.ufpr.br/direito/article/view/8872/6185. Acesso: 9 jul. 2020.

27 PASSOS, José Joaquim Calmon de. Ações cautelares. Revista da Faculdade de Direito da UFPR, Curitiba, v. 21, n..$^{\circ}$ 0, 1983, p. 49. Disponível em: https:/ / revistas.ufpr.br/direito/article/view/8872/6185. Acesso: 9 jul. 2020.

28 DIDIER JR., Fredie. Curso de direito processual civil. Salvador: JusPodivm, 2015, p. 582.

29 DIDIER JR., Fredie. Curso de direito processual civil. Salvador: JusPodivm, 2015, p. 581.

30 RIBEIRO, Leonardo Ferres da Silva. Tutela provisória (evolução e teoria geral). In: CAMPILONGO, Celso Fernandes; GONZAGA, Alvaro de Azevedo; FreIRE, André Luiz (coord.). Enciclopédia jurídica da PUCSP. São Paulo: Pontifícia Universidade Católica de São Paulo, 2017, p. 2. Tomo: Processo Civil. Disponível em: https://enciclopediajuridica.pucsp. br/verbete/166/edicao-1/tutela-provisoria-\%28evolucao-e-teoria-geral\%29. Acesso em: 24 out. 2018.

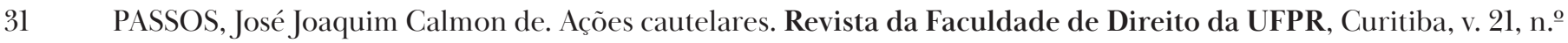
0, p. 29-62, 1983. Disponível em: https://revistas.ufpr.br/direito/article/view/8872/6185. Acesso: 9 jul. 2020. 
proferida em procedimento cautelar não antecipa a satisfação do autor quanto ao direito pleiteado, mas, ainda assim, era utilizada com esse objetivo ${ }^{32}$.

A questão começou a ter um rumo mais esclarecedor com o advento da Lei n.o 8.952/1994, que introduziu a redação do artigo 273 no Código de Processo Civil, para permitir a antecipação provisória dos efeitos da sentença em sede de decisão interlocutória, proferida dentro do processo de conhecimento, desde que houvesse prova inequívoca e verossimilhança nas alegações ${ }^{33}$ ou um juízo de probabilidade do direito ${ }^{34}$.

Pela lógica do CPC de 1973, a tutela cautelar tinha regime próprio e diferente da tutela antecipada, que poderia ser concedida em quatro hipóteses: a) a tutela antecipada de urgência, fundamentada na possibilidade de dano irreparável ou de difícil reparação; b) a tutela antecipada repressiva do abuso do direito de defesa ou de manifesto propósito protelatório da parte contrária; c) a tutela antecipada fundamentada em pedido incontroverso; d) a antecipação da tutela da pretensão recursal ${ }^{35}$.

O Código de Processo Civil em vigor unificou o instituto da tutela provisória (sob fundamento cautelar, antecipada e de evidência), passando a tratar de suas espécies nos artigos 294 a 311, com base em suas caraterísticas comuns, regulando as diferenças em tópicos próprios.

32 GRECO, Leonardo. Instituições de processo civil: processo de conhecimento. 3. ed. Rio de Janeiro: Forense, 2011, p. 352-353.

33 GRECO, Leonardo. Instituições de processo civil: processo de conhecimento. 3. ed. Rio de Janeiro: Forense, 2011, p. 353.

34 RIBEIRO, Leonardo Ferres da Silva. Tutela provisória (evolução e teoria geral). In: CAMPILONGO, Celso Fernandes; GONZAGA, Alvaro de Azevedo; FreIRE, André Luiz (coord.). Enciclopédia jurídica da PUCSP. São Paulo: Pontifícia Universidade Católica de São Paulo, 2017, p. 2. Tomo: Processo Civil. Disponível em: https://enciclopediajuridica.pucsp. br/verbete/166/edicao-1/tutela-provisoria-\%28evolucao-e-teoria-geral\%29. Acesso em: 24 out. 2018.

35 GRECO, Leonardo. Instituições de processo civil: processo de conhecimento. 3. ed. Rio de Janeiro: Forense, 2011, p. 353. 
Com base no Código e na doutrina, destacam-se as principais características da tutela provisória ou preventiva, que a distingue da tutela reparatória, que são: inércia ${ }^{36}$, provisoriedade ${ }^{37}$, instrumentalidade ${ }^{38}$, revogabilidade ${ }^{39}$, fungibilidade ${ }^{40}$ e cognição sumária ${ }^{4142}$.

As tutelas provisórias têm a função de dar maior efetividade ao processo, na medida em que garantem, asseguram, satisfazem o provimento final e permitem a melhor distribuição do ônus temporal ${ }^{43}$.

Consoante a sistemática legal vigente, a tutela antecipatória é dependente de uma decisão final a ser prolatada em cognição exauriente. Trata-se de uma decisão provisória que necessita de uma confirmação por meio de outra, dessa vez definitiva e exauriente, ou seja, sempre estará condicionada a uma etapa subsequente, amparada por um juízo de certeza ${ }^{44}$, salvo na estabilização de seus efeitos.

A tutela provisória é classificada pelo CPC com base nos seguintes critérios: a) o critério da natureza da providência pleiteada, de acordo com o qual a tutela divide-se em urgência e evidência; b) o critério funcional, que diz respeito à finalidade da tutela requerida, podendo estar relacionada à preservação ou à implementação de determinada situação de fato ou jurídica, subdividindo-se, portanto, a tutela provisória de urgência em cautelar e antecipada; c) o critério temporal, uma vez que a tutela

$36 \quad$ A inércia é uma das garantias gerais do processo civil, segundo a qual não haverá jurisdição ex officio, que só poderá ser exercida a partir da iniciativa dos sujeitos interessados (GRECO, Leonardo. A tutela da urgência e a tutela da evidência no Código de Processo Civil de 2015. In: MACÊDO, Lucas Buril de; PEIXOTO, Ravi; FREIRE, Alexandre (org.). Procedimentos especiais, tutela provisória e direito transitório. 2. ed. Salvador: JusPodivm, 2016, p. 186. (Coleção Novo CPC, Doutrina Selecionada, 4).

37 A provisoriedade (salvo na estabilização de seus efeitos) traz a ideia de que não se consolida a situação jurídica pretendida pelo litigante, visto que, ainda que respaldada pelos requisitos essenciais à concessão de tutelas de urgência e de evidência, enfrenta uma cognição superficial (GRECO, Leonardo. A tutela da urgência e a tutela da evidência no Código de Processo Civil de 2015. In: MACÊDO, Lucas Buril de; PEIXOTO, Ravi; FREIRE, Alexandre (org.). Procedimentos especiais, tutela provisória e direito transitório. 2. ed. Salvador: JusPodivm, 2016, p. 189. (Coleção Novo CPC, Doutrina Selecionada, 4).

38 A instrumentalidade diz respeito ao caráter acessório da tutela definitiva, por ficar condicionada à tutela principal pretendida ao final da demanda, salvo na estabilização de seus efeitos GRECO, Leonardo. A tutela da urgência e a tutela da evidência no Código de Processo Civil de 2015. In: MACÊDO, Lucas Buril de; PEIXOTO, Ravi; FREIRE, Alexandre (org.). Procedimentos especiais, tutela provisória e direito transitório. 2. ed. Salvador: JusPodivm, 2016, p. 189-190. (Coleção Novo CPC, Doutrina Selecionada, 4).

39 A revogabilidade, como consequência da provisoriedade e da instrumentalidade, versa sobre a possibilidade de reversão ou de alteração da tutela, pois pode ser revogada ou modificada a qualquer tempo, conforme determina a redação do artigo 296, caput, do CPC (RIBEIRO, Leonardo Ferres da Silva. Tutela provisória (evolução e teoria geral). In: CAMPILONGO, Celso Fernandes; GONZAGA, Alvaro de Azevedo; FREIRE, André Luiz (coord.). Enciclopédia jurídica da PUCSP. São Paulo: Pontifícia Universidade Católica de São Paulo, 2017, p. 9. Tomo: Processo Civil. Disponível em: https: / / enciclopediajuridica.pucsp.br/verbete/166/edicao-1/tutela-provisoria-\%28evolucao-e-teoria-geral\%29. Acesso em: 24 out. 2018.

40 A fungibilidade confere ao juiz poder para adequar a tutela provisória. O juiz pode converter a tutela antecipada em cautelar e vice-versa, se assim entender necessário (GRECO, Leonardo. A tutela da urgência e a tutela da evidência no Código de Processo Civil de 2015. In: MACÊDO, Lucas Buril de; PEIXOTO, Ravi; FREIRE, Alexandre (org.). Procedimentos especiais, tutela provisória e direito transitório. 2. ed. Salvador: JusPodivm, 2016, p. 194-195. (Coleção Novo CPC, Doutrina Selecionada, 4).

41 A cognição sumária é o tipo de cognição limitada à superficialidade, é um processo decisivo incompleto, pois almeja extrair uma conclusão rápida a respeito da necessidade da medida ((GRECO, Leonardo. A tutela da urgência e a tutela da evidência no Código de Processo Civil de 2015. In: MACÊDO, Lucas Buril de; PEIXOTO, Ravi; FREIRE, Alexandre (org.). Procedimentos especiais, tutela provisória e direito transitório. 2. ed. Salvador: JusPodivm, 2016, p. 195-196. (Coleção Novo CPC, Doutrina Selecionada, 4).

42 SILVA, Sandoval Alves da; SILVA, Barbie Chaves. A estabilização dos efeitos da tutela antecipada contra a Fazenda Pública como instrumento de efetivação dos direitos sociais. Revista Brasileira de Direito Processual, Belo Horizonte, ano 28, n. 111, [jul./set. 2020]. No prelo.

43 SILVA, Sandoval Alves da; SILVA, Barbie Chaves. A estabilização dos efeitos da tutela antecipada contra a Fazenda Pública como instrumento de efetivação dos direitos sociais. Revista Brasileira de Direito Processual, Belo Horizonte, ano 28, n. 111, [jul./set. 2020]. No prelo.

44 VALIM, Pedro Losa Loureiro. A estabilização da tutela antecipada. Revista Eletrônica de Direito Processual, Rio de Janeiro, v. 16, n. 16, jul./dez. 2015, p. 492. 
provisória poderá ser requerida antes do processo ou no decurso dele, sendo antecedente ou incidental, respectivamente ${ }^{45}$.

A urgência ocorre quando presentes a probabilidade do direito e o perigo de dano ou risco ao resultado útil do processo (o fumus boni iuris e o periculum in mora) ${ }^{46}$, conforme prescreve o artigo 300 do CPC, e a evidência, quando verificadas algumas das hipóteses previstas no artigo 311, incisos I a IV.

A tutela de evidência sempre será incidental, requerida na própria inicial ou por meio de petição avulsa, e tutelará provisoriamente o pedido do autor independentemente da urgência, em razão unicamente da probabilidade do direito ${ }^{47}$; já a tutela de urgência requer também o perigo de dano ou o risco ao resultado útil do processo.

Como se observa, a tutela provisória de urgência tem dois propósitos: a) cautelar, para proteger determinada situação, buscando a eficácia do processo por meio da conservação do direito objeto da lide para que ele possa ser usufruído por seu titular em momento ulterior - no encerramento da demanda; b) antecipada, concedendo o adiantamento da fruição ou uma satisfação do direito pretendido pelo autor com o encerramento do processo ${ }^{48}$.

Na unificação dos institutos da tutela provisória de urgência, o CPC de 2015 generalizou a possibilidade temporal de ser antecedente para a tutela cautelar e a tutela antecipada, diferentemente do CPC de 1973, que possibilitava essa hipótese somente ao processo cautelar antecedente, como uma forma de preparação para o processo principal ${ }^{49}$. Aplicando-se também à antecipação dos efeitos requerida em caráter antecedente (tutela antecipada antecedente), os artigos 303 e 304 dispõem sobre o requerimento da antecipação dos efeitos e da sua estabilização, respectivamente, de forma que a peça introdutória será proposta de forma simplificada, sem que seja necessária a observância fiel dos requisitos de uma petição inicial, nos termos do artigo 319 do CPC, demonstrando a probabilidade do direito, o perigo de dano ou o resultado útil do processo e os contornos do pedido principal. Tais requisitos são necessários para verificar o alcance e os efeitos da concessão da medida, bem como o prazo de quinze dias ou outro determinado pelo juiz para o aditamento da inicial, sendo vedada a alteração do pedido principal ${ }^{50}$.

Feitas as considerações de Calmon de Passos sobre as tutelas preventivas e o tratamento do CPC sobre as tutelas provisórias, cabe abordar a estabilização dos efeitos, especialmente nas demandas contra a Fazenda Pública e na concretização dos direitos sociais.

45 GRECO, Leonardo. Instituições de processo civil: processo de conhecimento. 3. ed. Rio de Janeiro: Forense, 2011, p. 360 .

46 Parte da doutrina critica fortemente a utilização desses termos, mas eles serão usados no presente trabalho por serem os mais usuais entre os juristas (SILVA, Sandoval Alves da; SILVA, Barbie Chaves. A estabilização dos efeitos da tutela antecipada contra a Fazenda Pública como instrumento de efetivação dos direitos sociais. Revista Brasileira de Direito Processual, Belo Horizonte, ano 28, n. 111, [jul./set. 2020]. No prelo).

47 GRECO, Leonardo. Instituições de processo civil: processo de conhecimento. 3. ed. Rio de Janeiro: Forense, 2011, p. 370 .

48 RIBEIRO, Leonardo Ferres da Silva. Tutela provisória (evolução e teoria geral). In: CAMPILONGO, Celso Fernandes; GONZAGA, Alvaro de Azevedo; FREIRE, André Luiz (coord.). Enciclopédia jurídica da PUCSP. São Paulo: Pontifícia Universidade Católica de São Paulo, 2017, p. 6. Tomo: Processo Civil. Disponível em: https:/ / enciclopediajuridica.pucsp. $\mathrm{br} /$ verbete/166/edicao-1/tutela-provisoria-\%28evolucao-e-teoria-geral\%29. Acesso em: 24 out. 2018.

49 RIBEIRO, Leonardo Ferres da Silva. Tutela provisória (evolução e teoria geral). In: CAMPILONGO, Celso Fernandes; GONZAGA, Alvaro de Azevedo; Freire, André Luiz (coord.). Enciclopédia jurídica da PUCSP. São Paulo: Pontifícia Universidade Católica de São Paulo, 2017, p. 32-33. Tomo: Processo Civil. Disponível em: https://enciclopediajuridica. pucsp.br/verbete/166/edicao-1/tutela-provisoria-\%28evolucao-e-teoria-geral\%29. Acesso em: 24 out. 2018.

50 RIBEIRO, Leonardo Ferres da Silva. Tutela provisória (evolução e teoria geral). In: CAMPILONGO, Celso Fernandes; GONZAGA, Alvaro de Azevedo; FreIRE, André Luiz (coord.). Enciclopédia jurídica da PUCSP. São Paulo: Pontifícia Universidade Católica de São Paulo, 2017, p. 33. Tomo: Processo Civil. Disponível em: https:/ / enciclopediajuridica.pucsp. br/verbete/166/edicao-1/tutela-provisoria-\%28evolucao-e-teoria-geral\%29. Acesso em: 24 out. 2018. 


\section{O fenômeno da estabilização como garantia de remoção do obstáculo jurídico para a fruição do bem da vida}

Ainda na vigência do CPC de 1973, após a concessão da antecipação dos efeitos em sede de tutela antecipada, os sujeitos desinteressavam-se pelo prosseguimento do processo mesmo com a fruição do bem demandado em juízo, o que trazia uma sobrecarga do Judiciário ${ }^{51}$ e se revelava sem sentido, pois o bem da vida era protegido e o obstáculo removido com a simples concessão da tutela antecipada.

O fardo suportado pelos sujeitos em juízo, nessas hipóteses, levou Ada Pellegrini Grinover a propor, em 1997, que uma decisão cujo teor deferisse integralmente uma tutela antecipada, quando não impugnada, converter-se-ia em sentença de mérito, de modo a formar coisa julgada material ${ }^{52}$. Essa ideia foi objeto do Projeto de Lei do Senado n.o 186, em 2005, que propôs a mesma solução ${ }^{53}$, buscando tornar definitivo e suficiente o que fora estabelecido pela decisão antecipatória.

O fenômeno processual estabilitário de manutenção da eficácia da medida de urgência ou antecipatória de tutela tem inspiração alienígena no direito processual civil italiano. A mesma inspiração também é encontrada na juridiction des référés do direito francês ${ }^{54}$, que têm previsão expressa de manutenção da eficácia de uma medida antecipatória quando não houver impugnação da decisão que a concedeu ${ }^{55}$, conforme registro histórico na exposição de motivos do anteprojeto para o novo Código, elaborada em 2009 pela comissão de juristas nomeada pelo Senado Federal.

Como não há força de coisa julgada, qualquer um dos sujeitos poderá submeter o caso concreto à cognição exauriente, razão pela qual não se ofende o contraditório, a ampla defesa e o devido processo legal (jurídico), pois haverá a possibilidade de ajuizar um processo principal fundado em cognição plena $^{56}$.

O artigo 304 do Código de Processo Civil brasileiro prescreve que a decisão liminar torna-se estável quando da decisão que a conceder não for interposto o respectivo recurso, que seria o agravo de instrumento nos termos do artigo 1015, I, do CPC, mas a doutrina estende a qualquer outro tipo de impugnação, na medida em que se pode estar diante, por exemplo, de uma hipótese de sucedâneos recursais ou de suspensão de liminar de segurança ${ }^{57}$.

A estabilização provoca a extinção do processo sem formação de coisa julgada, pois, no prazo estipulado pelo CPC, os sujeitos envolvidos no litígio podem requerer a revisão, a reforma ou a invalidação

51 SCARPELLI, Natália Cançado. Estabilização da tutela provisória de urgência antecipada requerida em caráter antecedente. 2016. 186 f. Dissertação (Mestrado em Direito Processual Civil) - Pontifícia Universidade Católica de São Paulo, São Paulo, 2016, p. 11-14.

52 SILVA, Sandoval Alves da; SILVA, Barbie Chaves. A estabilização dos efeitos da tutela antecipada contra a Fazenda Pública como instrumento de efetivação dos direitos sociais. Revista Brasileira de Direito Processual, Belo Horizonte, ano 28, n. 111, [jul./set. 2020]. No prelo.

53 CARDOSO, Luiz Eduardo Galvão Machado. Estabilização da tutela antecipada. 2017. 177 f. Dissertação (Mestrado em Direito) - Universidade Federal da Bahia, Salvador, 2017, p. 40-50.

54 A juridiction des référés é um tipo de procedimento calcado em cognição sumária, que se concretiza por meio de uma decisão provisória, proferida por juiz distinto daquele competente para o julgamento do processo principal, com o poder de determinar imediatamente as medidas que entender necessárias ante a situação fática (SILVA, Sandoval Alves da; SILVA, Barbie Chaves. A estabilização dos efeitos da tutela antecipada contra a Fazenda Pública como instrumento de efetivação dos direitos sociais. Revista Brasileira de Direito Processual, Belo Horizonte, ano 28, n. 111, [jul./set. 2020]. No prelo).

55 SICA, Heitor Vitor Mendonça. Doze problemas e onze soluções quanto à chamada "estabilização da tutela antecipada”. Revista do Ministério Público do Rio de Janeiro, Rio de Janeiro, n. 55, jan./ mar. 2015, p. 87-91.

56 VALIM, Pedro Losa Loureiro. Référé francês e o instituto da estabilização da tutela antecipada. Revista Jus Navigandi, Teresina, ano 22, n. 5216, 12 out. 2017. Disponível em: https://jus.com.br/artigos/60593. Acesso em: 22 out. 2018.

57 SILVA, Sandoval Alves da. O Ministério Público e a concretização dos direitos humanos. Salvador: Juspodivm, $2016 \mathrm{a}$. 
da tutela estabilizada, visto que apenas conserva os efeitos da tutela concedida antecipadamente ${ }^{58}$, sem discutir o mérito de forma exauriente.

À semelhança da classificação de Calmon de Passos, essa hipótese seria uma medida substancial, procedimentalmente cautelar, pois busca impedir a constituição de uma situação-obstáculo de configuração certa e de ocorrência muito provável em futuro determinado correlacionado com o bem da vida a ser protegido preventivamente ${ }^{59}$. De fato, a estabilização dos efeitos de uma medida antecipatória surge como uma solução para a crise de direito material ${ }^{60}$, por representar uma alternativa célere à resolução de conflitos e por não se submeter a uma etapa processual posterior ${ }^{61}$.

As hipóteses de estabilização parecem vir de um raciocínio simples, visto que, concedida a tutela provisória em caráter antecipado antecedente, abre-se a possibilidade de estabilização de seus efeitos quando não for interposto recurso ou impugnação da decisão concessiva, na forma do artigo 304 do CPC. Porém, não é assim que se comporta o raciocínio mais complexo sobre a utilidade e a possibilidade desse instituto, que serve para desafogar o Poder Judiciário e proteger o bem da vida tutelado pela via jurisdicional.

Com efeito, cabe inicialmente asseverar as hipóteses em que não há estabilização, devendo o processo prosseguir normalmente, quais sejam: a) quando o autor emenda a inicial e o réu agrava ou impugna a decisão; b) quando o autor emenda a inicial requerendo o prosseguimento da demanda e o réu não agrava ou impugna a decisão, caso em que se atendem os interesses do autor; c) quando o autor não emenda a inicial e o réu agrava ou impugna a decisão, caso em que há a extinção do processo sem resolução de mérito e o recurso interposto é inadmitido, por falta de interesse processual de ambos.

De forma inversa, apresentar-se-ão hipóteses, mínimas a meu ver, em que se defende a estabilização dos efeitos da tutela requerida de forma antecedente com a consequente extinção do processo sem resolução de mérito: a) quando o autor emenda a inicial e o réu não agrava ou impugna a decisão; b) quando o autor emenda a inicial requerendo a desistência da ação e o réu não agrava ou impugna a decisão, o que demonstra a satisfação de ambos com o resultado alcançado; c) quando o autor não emenda a inicial e o réu não agrava ou impugna a decisão ${ }^{62}$; d) quando o autor emenda a inicial e o réu renuncia ao direito de impugnar ou recorrer; e) quando o autor não emenda a inicial ou emenda a inicial sem pedido de prosseguimento e o réu impugna ou recorre, porém desiste da impugnação ou recurso ${ }^{63}$; f) a qualquer momento por convenção processual, se assim estipularem os sujeitos processuais envolvidos.

Em se tratando da Fazenda Pública, defende-se mais uma hipótese "g", de estabilização dos efeitos concedidos em sede de tutela antecipada, qual seja: quando o autor não emenda a inicial simplificada ou desiste da emenda ou da ação, ainda que o réu agrave ou impugne o provimento judicial. Porém, nesses casos, a estabilização só ocorre quando a decisão aplicar teses ou precedentes judiciais ou administrativos formal ou materialmente vinculantes, fundados: g.l) em súmula de tribunal superior, g.2) em acórdão proferido pelo Supremo Tribunal Federal (STF) ou pelo Superior Tribunal de Justiça

$58 \quad$ SILVA, Sandoval Alves da; SILVA, Barbie Chaves. A estabilização dos efeitos da tutela antecipada contra a Fazenda Pública como instrumento de efetivação dos direitos sociais. Revista Brasileira de Direito Processual, Belo Horizonte, ano 28, n. 111, [jul./set. 2020]. No prelo.

59 PASSOS, José Joaquim Calmon de. Ações cautelares. Revista da Faculdade de Direito da UFPR, Curitiba, v. 21, n.o 0, p. 29-62, 1983. Disponível em: https:/ / revistas.ufpr.br/direito/article/view/8872/6185. Acesso: 9 jul. 2020.

60 NUNES, Dierle; ANDRADE, Érico. Os contornos da estabilização da tutela provisória de urgência antecipatória no Novo CPC e o mistério da ausência de formação da coisa julgada. In: MACÊDO, Lucas Buril de; PEIXOTO, Ravi FREIRE, Alexandre (org.). Procedimentos especiais, tutela provisória e direito transitório. 2. ed. Salvador: JusPodivm, 2016, p. 82. (Coleção Novo CPC, Doutrina Selecionada, 4).

61 VALIM, Pedro Losa Loureiro. A estabilização da tutela antecipada. Revista Eletrônica de Direito Processual, Rio de Janeiro, v. 16, n. 16, jul./dez. 2015, p. 492-493.

62 SILVA, Sandoval Alves da. Aula 4: Estabilização dos efeitos da tutela provisória. Videoaula 2016: Novo Código de Processo Civil. Dez. 2016b. 1 vídeo (17 min). Disponível em: https: / /www.youtube.com /watch?v=pisbjvCCydM\&t=308s. Acesso em: 3 nov. 2018.

63 SILVA, Sandoval Alves da; SILVA, Barbie Chaves. A estabilização dos efeitos da tutela antecipada contra a Fazenda Pública como instrumento de efetivação dos direitos sociais. Revista Brasileira de Direito Processual, Belo Horizonte, ano 28, n. 111, [jul./set. 2020]. No prelo. 
(STJ), g.3) em julgamento de recursos repetitivos, g.4) em entendimento firmado em incidente de resolução de demandas repetitivas ou de assunção de competência e g.5) em entendimento coincidente com orientação vinculante firmada no âmbito administrativo do próprio ente público, consolidada em manifestação, parecer ou súmula administrativa, caso em que há a extinção do processo sem resolução de mérito e o recurso interposto é inadmitido, por falta de interesse processual de ambas as partes e para a remessa necessária.

Obviamente que a estabilização não significa impossibilidade de revisão dos efeitos estabilizados, pois qualquer uma das partes pode submeter o caso concreto à cognição plena e exauriente para rever, reformar ou invalidar o direito material objeto da antecipação, no prazo decadencial de dois anos.

O tema é recente e suscita muitas dúvidas, mas, se há pretensão à estabilização, deve-se levar em consideração o elemento volitivo para se alcançar maior êxito, de forma que o autor deverá indicar expressamente na petição inicial simplificada que pretende valer-se do que consta no artigo 304 do CPC, com pedido de prazo ampliado para alcançar os efeitos pretendidos, sob pena de gerar confusão entre o prazo de emenda do autor e os prazos de impugnações a que se submete a decisão concessiva.

Nesse sentido, o juiz pode conferir um prazo para emenda superior aos prazos de recurso ou impugnação, permitindo a atuação resolutiva na crise de direito material; por outro lado, o réu deve manter-se inerte quanto à interposição de recurso ou à apresentação de qualquer impugnação, ou renunciar ou desistir do direito de recorrer ou impugnar, caso se pretenda praticar o ato processual ou já tenha sido praticado, respectivamente.

Com a estabilização dos efeitos da tutela antecipada antecedente, possibilita-se a solução de um litígio com base na cognição sumária, tratando-se de hipótese em que as partes se conformam (ainda que provisoriamente) com os termos da decisão que concede a tutela antecipada ${ }^{64}$, de forma que a estabilização se revela como instrumento processual de efetividade da tutela jurisdicional sem resolução de mérito, aliada à celeridade que rodeia uma decisão calcada em cognição sumária, concretizando os direitos sociais de maneira célere e eficaz ${ }^{65}$.

Diante da clara e expressa possibilidade de estabilização dos efeitos da tutela definitiva concedida em caráter antecedente, conforme previsão no artigo 304 do CPC, cabe abordar as hipóteses em que se aplica tal instituto contra a Fazenda Pública, mesmo diante de tantas prerrogativas do Poder Público em juízo, que parecem prima facie guardar forte incompatibilidade de aplicação, como prazo em dobro, remessa necessária etc., conforme apresentação abaixo.

\section{As hipóteses de estabilização dos efeitos da tutela antecipada antecedente contra a Fazenda Pública}

A estabilização dos efeitos da tutela definitiva concedida em caráter provisório pode e deve ser aplicada contra a Fazenda Pública para a concretização dos direitos humanos e nas hipóteses em que tais prerrogativas não são óbices à aplicação, ainda que a doutrina não seja uníssona nesse sentido.

Os encontros de processualistas e de juízes para discutir o tema já registram posicionamento no sentido da aplicabilidade. É o caso do Enunciado n.․5 582 do Fórum Permanente de Processualistas Civis (FPPC) ${ }^{66}$ e do Enunciado n. 21 sobre o CPC/2015 do Tribunal de Justiça do Estado de Minas Gerais $(\mathrm{TJMG})^{67}$, que proclamaram o cabimento. Essa posição, porém, não foi cotejada com os obstáculos

64 AMARAL, Fernando Henrique de Abreu. A tutela provisória contra a Fazenda Pública no novo CPC. 2016. Trabalho de Conclusão de Curso (Graduação em Direito) - Universidade Federal do Rio Grande do Sul, Porto Alegre, 2016, p. 54 .

65 SILVA, Sandoval Alves da; SILVA, Barbie Chaves. A estabilização dos efeitos da tutela antecipada contra a Fazenda Pública como instrumento de efetivação dos direitos sociais. Revista Brasileira de Direito Processual, Belo Horizonte, ano 28, n. 111, [jul./set. 2020]. No prelo.

66 “(arts. 304, caput; 5.․ㅡ caput e inciso XXXV, CF) Cabe estabilização da tutela antecipada antecedente contra a Fazenda Pública. (Grupo: Tutela provisória)".

67 "A Fazenda Pública se submete ao regime de estabilização da tutela antecipada, por não se tratar de cognição exauriente sujeita a remessa necessária”. 
possivelmente enfrentados em razão das prerrogativas processuais da Fazenda Pública, o que já tem sido tratado academicamente ${ }^{68}$.

Assim, cabe aqui catalogar os argumentos que demonstram a aplicabilidade do instituto diante da Fazenda Pública e as hipóteses na legislação e nos precedentes do STF que demonstram a possibilidade de estabilização dos efeitos concedidos em caráter antecedente.

O primeiro argumento nessa defesa vem do cabimento de ação monitória contra a Fazenda Pública, nos termos do artigo 700 do CPC. O cabimento da ação monitória, de forma geral, fundamenta-se na existência de provas, escritas ou orais, documentadas pelo instituto da produção antecipada de provas (art. 381, § 2.․o, do CPC), que não têm força de título executivo, mas, com seu manejo em juízo, há a pretensão de converter tais provas em título executivo com a exigência judicial para o devedor de pagamento de montante em dinheiro, de entrega de coisa fungível ou infungível, de entrega de bem móvel ou imóvel e de adimplemento de obrigação de fazer ou de não fazer.

Deve-se lembrar que, pela interpretação do CPC, ainda que o credor seja detentor de título executivo extrajudicial, é admissível o cabimento da ação monitória, a legislação processual não veda que o portador de um título executivo extrajudicial opte por submetê-lo ao processo de conhecimento para a obtenção do título executivo judicial, nos termos do artigo 785 do CPC, servindo o procedimento monitório para requerer a confirmação judicial do direito ${ }^{69}$.

O raciocínio comparativo é compatível entre os dois institutos, pois ambos os regimes - o da estabilização e o da ação monitória - dão efeitos à não impugnação pelo réu ou devedor, visto que, no procedimento monitório, o não cumprimento do mandado e a não oposição de embargos converterão o mandado judicial em título executivo judicial, a despeito de qualquer formalidade.

Assim, tem-se que a decisão, pautada por uma cognição sumária e incompleta, tão logo determine a satisfação da obrigação, verificará a confiabilidade do documento apresentado e a credibilidade do direito pleiteado ${ }^{70}$. Porém, o procedimento monitório converter-se-á em processo de conhecimento caso a decisão seja impugnada por meio de embargos à ação monitória, suspendendo-se a eficácia do mando monitório.

O CPC de 2015, no $§ 6 .^{\circ}$ do artigo 700 e no $§ 4 .^{\circ}$ do artigo 701, positiva expressamente a hipótese de cabimento da ação monitória contra a Fazenda Pública, demonstrando a concordância legislativa com o entendimento sumular consagrado no STJ no ano de 2007 com a Súmula n. 939, devendo apenas serem observadas as prerrogativas processuais da Fazenda Pública, no que couber.

Com efeito, os aspectos semelhantes da ação monitória e da tutela antecipada antecedente fundamentam a possibilidade de estabilização contra a Fazenda Pública ${ }^{71}$, de forma que se pode asseverar que a estabilização da tutela provisória e a ação monitória no atual CPC instituem uma sistemática de tutela de direitos por meio da técnica monitória, a partir da qual é possível obter um provimento judicial que perdure no tempo, visto que estável ou definitivo, respectivamente, com fundamento em uma cognição sumária ou incompleta ${ }^{72}$.

Em que pese a indicação de uma aplicação ampla, a viabilidade da ação monitória contra a Fazenda Pública constitui argumento pertinente para demonstrar que é igualmente possível a estabilização dos

68 SILVA, Sandoval Alves da; SILVA, Barbie Chaves. A estabilização dos efeitos da tutela antecipada contra a Fazenda Pública como instrumento de efetivação dos direitos sociais. Revista Brasileira de Direito Processual, Belo Horizonte, ano 28, n. 111, [jul./set. 2020]. No prelo.

69 CUNHA, Leonardo Carneiro da. A Fazenda Pública em juízo. 14. ed. Rio de Janeiro: Forense, 2017 , p. $498-499$.

70 CUNHA, Leonardo Carneiro da. A Fazenda Pública em juízo. 14. ed. Rio de Janeiro: Forense, 2017 , p. 502.

71 CASTRO, Thaise Braga. Tutela provisória: tutela da urgência e a estabilização da demanda. Revista Jurídica da Procuradoria-Geral do Distrito Federal, Brasília, DF, v. 40, n. 2, jul./dez. 2015, p. 26. 
efeitos de um provimento antecipatório ${ }^{73}$, com as análises à luz das prerrogativas processuais da Fazenda Pública $^{74}$.

A primeira hipótese em que se defende a estabilização dos efeitos na concessão de tutela provisória é referente às obrigações de fazer, não fazer e dar contra a Fazenda Pública, pois nessas espécies de obrigações não há óbices, visto que a legislação não oferece obstáculos, principalmente porque para esses tipos de obrigação não há a exigência constitucional do precatório ${ }^{75}$, embora algumas decisões possam influir indiretamente no orçamento público ${ }^{76}$.

A segunda análise que cabe destacar diz respeito às restrições impostas à tutela antecipada contra a Fazenda Pública, declaradas constitucionais na decisão proferida na ADC n. $\stackrel{-}{4}$. A própria jurisprudência do STF mitigou o entendimento acerca das vedações à concessão de tutela antecipada contra a Fazenda Pública, excepcionando o efeito vinculante da referida decisão ${ }^{77} \mathrm{em}$ várias hipóteses, como é o caso dos direitos previdenciários reconhecidos constitucionalmente, nos termos da Súmula n.o 729 do STF.

Em terceiro lugar, ainda buscando as hipóteses de atendimento aos direitos sociais, cabe destacar a Suspensão de Tutela Antecipada (STA) n. ${ }^{o}$ 175, que consagrou o entendimento do STF sobre a judicialização do direito à saúde, em especial, sobre fornecimento de medicamentos, criação de vagas em UTI, realização de cirurgias, contratação de servidores, fornecimento de tratamentos fora do domicilio e no exterior. Prevaleceu o posicionamento de que o Poder Público não pode manter-se omisso em relação aos problemas ligados à saúde pública ${ }^{78}$, após audiência pública realizada nos autos do processo.

No julgamento, após muito debates, o STF considerou a inconstitucionalidade por omissão na inércia do Poder Público quanto à concretização do direito à saúde que, como direito social fundamental, deve estar ao alcance de todos, sendo papel do Estado garantir-lhe o acesso universal ${ }^{79}$, razão pela qual se defende a estabilização de tutela antecipada nas hipóteses encontradas na STA n.. 175 , com fundamento na vinculação material dos precedentes ${ }^{80}$, principalmente agora em tempos de pandemia da COVID-19.

A quarta hipótese tem assento nos precedentes do STF, que também se tem manifestado pela concessão antecipada dos efeitos da tutela nos casos que envolvem o pagamento de parcela indenizatória, quando não se tratar de imposição direta ao pagamento de vantagem, mas quando o pagamento é realizado como consequência da medida antecipatória. É o caso da nomeação de candidato aprovado em concurso público, o qual perceberá remuneração referente ao respectivo cargo público, o que envolve questões orçamentárias ou repercussões financeiras como consequência secundária (ou indireta) da decisão ${ }^{81}$.

73 CUNHA, Leonardo Carneiro da. A Fazenda Pública em juízo. 14. ed. Rio de Janeiro: Forense, 2017, p. 323.

74 SILVA, Sandoval Alves da; SILVA, Barbie Chaves. A estabilização dos efeitos da tutela antecipada contra a Fazenda Pública como instrumento de efetivação dos direitos sociais. Revista Brasileira de Direito Processual, Belo Horizonte, ano 28, n. 111, [jul./set. 2020]. No prelo.

75 DIDIER JR., Fredie; BRAGA, Paula Sarno; OLIVEIRA, Rafael Alexandria de. Curso de direito processual: teoria da prova, direito probatório, decisão, precedente, coisa julgada e tutela provisória. 12. ed. Salvador: JusPodivm, 2017, p. 725.

76 SILVA, Sandoval Alves da; SILVA, Barbie Chaves. A estabilização dos efeitos da tutela antecipada contra a Fazenda Pública como instrumento de efetivação dos direitos sociais. Revista Brasileira de Direito Processual, Belo Horizonte, ano 28, n. 111, [jul./set. 2020]. No prelo.

77 MAGALHÃES, Breno Baía; SILVA, Sandoval Alves da. O grau de vinculação dos precedentes à luz do STF: o efeito vinculante é absoluto? Revista de Informação Legislativa, Brasília, DF, v. 49, n. 195, jul./set. 2012, p. 88-89.

78 VAlle, Gustavo Henrique Moreira do; CAMARGO, João Marcos Pires. A audiência pública sobre a judicialização da saúde e seus reflexos na jurisprudência do Supremo Tribunal Federal. Revista de Direito Sanitário, São Paulo, v. 11, n. 3, fev. 2011, p. 22.

79 BERTAGNOLLI, Ilana. Judicialização do direito fundamental à saúde: uma análise do Ag. Reg. na Suspensão de Tutela Antecipada: STA n. 175-CE. Revista USCS - Direito, São Caetano do Sul, ano X, n. 20, jan./jun. 2011, p. 112-123.

80 Para detida análise da questão, consultar: MAGALHÃES, Breno Baía; SILVA, Sandoval Alves da. O grau de vinculação dos precedentes à luz do STF: o efeito vinculante é absoluto? Revista de Informação Legislativa, Brasília, DF, v. 49, n. 195, p. 77-96, jul./set. 2012.

81 CUNHA, Leonardo Carneiro da. A Fazenda Pública em juízo. 15. ed. rev. atual. e ampl. Rio de Janeiro: Forense, 2018 , p. 326. 
Um dos empecilhos à estabilização que se poderia aventar seria o prazo em dobro para todos os seus atos processuais e a intimação pessoal do advogado público, mas isso não é óbice, pois a intimação pessoal não tem qualquer incompatibilidade com o sistema de estabilização, e a dilação dobrada de prazo pode ser superada pela concessão pelo juiz de prazo de emenda do autor superior ao prazo para qualquer impugnação da Fazenda pública, no forma do artigo 303, § 1., I, do CPC. Ademais, essas situações ocorrem na ação monitória, e mesmo assim não se trata de empecilho.

Outro possível óbice à estabilização dos efeitos da tutela antecipada antecedente contra a Fazenda Pública que se poderia argumentar seria a prerrogativa da remessa necessária, segundo a qual as sentenças proferidas contra a União, os Estados, o Distrito Federal, os Municípios e suas respectivas autarquias e fundações de direito público sujeitam-se obrigatoriamente ao duplo grau de jurisdição, salvo exceções legais. A superação do óbice reside em boa parte nas exceções legais e na ideia de que a ocorrência da estabilização não se confunde com a formação de coisa julgada, não se sujeitando ao reexame obrigatório para que produza seus efeitos ${ }^{82}$, porque a estabilização não significa imutabilidade.

Por fim, cabe verificar a prerrogativa processual da Fazenda Pública referente ao sistema especial de pagamento de débitos mediante precatórios, nos termos do artigo 100 da Constituição, visto que o referido dispositivo tem como fundamento a viabilidade e a previsibilidade orçamentária de pagamento, de modo que a concessão reiterada de tutelas provisórias não prejudique as contas públicas ${ }^{83}$.

Entretanto, garantida a previsibilidade orçamentária, nada obsta a que a obrigação imposta pela tutela de urgência deferida contra a Fazenda Pública seja adimplida por meio desse sistema ${ }^{84}$, de maneira que esse fato implicaria tão somente a condução antecipada da provável parte vitoriosa na "fila de espera" para a expedição do respectivo precatório ${ }^{85}$, sob a condição de ser confirmada pela decisão transitada em julgado ou estabilizada, se for o caso.

Caso o valor se enquadre como requisição de pequeno valor - RPV (ou de crédito superpreferencial - doença grave, pessoas com deficiência e sexagenários), o pagamento poderá ocorrer pelo sistema de urgência no pagamento de obrigações oriundas de provimentos judiciais ${ }^{86}$, com a simples alocação orçamentária da RPV ou do crédito superpreferencial no ano em que forem requisitados.

Apesar de o caput do artigo 100 da CRFB ter uma indicação no dispositivo de que os pagamentos se fariam por meio de precatório, essa interpretação não parece ser aplicável a todos os caso, porque o $\S 2^{\circ}$ do próprio dispositivo também prescreve que os créditos superpreferenciais serão pagos com preferência sobre todos os demais débitos, preferindo, a nosso ver, inclusive os débitos de pequeno valor, porque visa a proteger a vida e é consonante com o princípio da dignidade da pessoa humana e dos direitos fundamentais consagrados na Constituição referente à saúde e à proteção ao idoso.

As referências à palavra "precatório" insertas no caput e $\$ \S$ do artigo 100 não representam submissão a esse sistema de pagamento de todos os débitos da Fazenda Pública, mas sim de que há hipótese em que a verificação da situação especial ou de exceção ocorre. Por outras palavras, o crédito é processado pelo sistema de precatório até ser revelada a necessidade da tutela de pagamento de urgência com a constatação da característica de sexagenário (em razão da idade) ou de doença grave (em razão do risco de vida), momento em que o pagamento sai do sistema de precatório e passa a ser processado de forma direta, pois só dessa forma se entende a imposição do parágrafo de que tais obrigações serão pagas com preferência sobre todos os demais débitos - crédito superpreferencial.

82 CUNHA, Leonardo Carneiro da. A Fazenda Pública em juízo. 14. ed. Rio de Janeiro: Forense, 2017, p. 323.

83 RISSO, Edimara Sachet; BUZETTI, Jorge Augusto. A possibilidade de deferimento da tutela antecipada em face da Fazenda Pública. Revista Faz Ciência, [s.l.], v. 11, n. 14, jul./dez. 2009, p. 30-31.

84 RISSO, Edimara Sachet; BUZETTI, Jorge Augusto. A possibilidade de deferimento da tutela antecipada em face da Fazenda Pública. Revista Faz Ciência, [s.l.], v. 11, n. 14, jul./dez. 2009, p. 31.

85 DIDIER JR.; BRAGA; OLIVEIRA, 2008, p. 669, apud RISSO, Edimara Sachet; BUZETTI, Jorge Augusto. A possibilidade de deferimento da tutela antecipada em face da Fazenda Pública. Revista Faz Ciência, [s.l.], v. 11, n. 14, jul./ dez. 2009, p. 31.

86 Para um estudo mais aprofundado sobre o tema consultar: SILVA, Sandoval Alves da. Aspectos orçamentários e constitucionais da requisição de pequeno valor - RPV. In: José Mauricio Conti, Fernando Facury Scafff. (Org.). ORÇAMENTOS PÚBLICOS E DIREITO FINANCEIRO. 1ed.SAO PAULO: REVISTA DOS TRIBUNAIS, 2011, v. 1, p. 461-489. 
Nesse sentido, sem a preocupação de ser fiel à ordem cronológica das alterações constitucionais ${ }^{87}$, registram-se, como outra tentativa de estabelecer um regime de pagamento diferenciado e mais célere que os precatórios, com a redação trazida pela Emenda Constitucional n.. 62/2009 ao $§ 2^{\text {o88 }}$, do artigo 100 da CRFB, quais sejam, os créditos sexagenários, de pessoas com deficiência ou de portadores de doença grave ${ }^{89}$, que incialmente não teve um tratamento de pagamento diferenciado, mas apenas um regime de preferência dentro dos precatórios à semelhança do que ocorrera com os créditos de natureza alimentar, conforme definido inicialmente no artigo 10 da Resolução n ${ }^{\circ} 115 / 2010$ - $\mathrm{CNJ}^{90}$ e no art. 19 da Resolução, n 122/2010 - CJF¹.

Tal situação foi duramente criticada pela doutrina, por representar, à semelhança dos créditos alimentares, mais um atentado à dignidade da pessoa humana, agora com mais força, pois trata-se de alguém da terceira idade ou de necessidades prementes imprescindíveis para salvar a vida com a doença de que é acometido ${ }^{92}$.

Felizmente a crítica foi atendida, apesar de questionamentos sobre a constitucionalidade, com a revogação das Resoluções do CNJ e do CJF, dando tratamento de pagamento, à semelhança de RPV, admitindo parcelamento para atender aos créditos de doença grave, pessoas com deficiência e os sexagenários - créditos superpreferencial. Chama-se atenção nessa regulação para os parágrafos $3^{\circ}$ e $4^{\circ}$, do artigo 9o, da Resolução n⿳o 303/2019 - CNJ ${ }^{93}$ e ao artigo 13 da Resolução no CJF ${ }^{94}$, que deu caráter de crédito superpreferencial sem submeter ao regime de precatório e ao de prioridade aos créditos alimentares, respectivamente, demonstrando uma cadeia de prioridade aos créditos com pagamento em regime de urgência aos portadores de doença grave, em seguida, às pessoas com deficiência e, posteriormente aos idosos com 60 anos completos na data do pagamento, limitado ao triplo do valor determinado para as requisições de pequeno valor.

87 As exceções ao sistema de precatórios iniciaram-se na ordem cronológica com os créditos alimentares, já com a redação constitucional original, que foi afastada pelo STF, súmula 655; posteriormente com a inclusão dos créditos de pequeno valor, pela EC 20/98 e agora com os créditos alimentícios dos sexagenários e de portadores de doença grave, limitado ao triplo do valor determinado para as requisições de pequeno valor, trazida pela EC 62/2009.

88 CRFB: Art. 100... $\$ 2^{\circ}$ Os débitos de natureza alimentícia cujos titulares tenham 60 (sessenta) anos de idade ou mais na data de expedição do precatório, ou sejam portadores de doença grave, definidos na forma da lei, serão pagos com preferência sobre todos os demais débitos, até o valor equivalente ao triplo do fixado em lei para os fins do disposto no $§$ $3^{\circ}$ deste artigo, admitido o fracionamento para essa finalidade, sendo que o restante será pago na ordem cronológica de apresentação do precatório.

$89 \quad \mathrm{O} \S 2^{\circ}$ do art. 100 teve a constitucionalidade questionada em relação ao limite posto pelo dispositivo. De qualquer forma a inovação é louvável, pois criou uma hipótese preferência aos que necessitam em razão da idade ou de doença grave. Espera-se que o STF não declare a inconstitucionalidade total do dispositivo, mantendo-se a inovação e atendo-se apenas ao limite.

90 Art. 10. O pagamento preferencial previsto no $§ 2^{o}$ do art. 100 da CF será efetuado por credor e não importará em ordem de pagamento imediato, mas apenas em ordem de preferência.

91 Art. 19. A prioridade dos créditos dos portadores de doenças graves e maiores de 60 anos será limitada ao triplo do valor estipulado para as requisições de pequeno valor, não importando em ordem de pagamento imediato, mas apenas em ordem de preferência.

92 SILVA, Sandoval Alves da. Aspectos orçamentários e constitucionais da requisição de pequeno valor - RPV. In: José Mauricio Conti, Fernando Facury Scafff. (Org.). ORÇAMENTOS PÚBLICOS E DIREITO FINANCEIRO. led.SAO PAULO: REVISTA DOS TRIBUNAIS, 2011, v. 1, p. 468-469.

93 Art. 9º Os débitos de natureza alimentícia cujos titulares, originários ou por sucessão hereditária, sejam idosos, portadores de doença grave ou pessoas com deficiência, assim definidos na forma da lei, serão pagos com preferência sobre todos os demais, até a monta equivalente ao triplo fixado em lei como obrigação de pequeno valor, admitido o fracionamento do valor da execução para essa finalidade.

§ $3^{\circ}$ Deferido o pedido, o juízo da execução expedirá a requisição judicial de pagamento, distinta de precatório, necessária à integral liquidação da parcela superpreferencial, limitada ao valor apontado no caput deste artigo.

$\S 4^{\circ}$ A expedição e pagamento da requisição judicial de que trata o § 3odeste artigo observará o disposto no art. 47 e seguintes desta Resolução, no art. 17 da Lei no10.259, de 12 de julho de 2011, no art. 13, inciso I, da Lei no12.153, de 22 de dezembro de 2009, e no art. 535, §3o, inciso II, do Código de Processo Civil.

94 Art. 13. Os débitos de natureza alimentícia serão pagos com preferência sobre os demais, respeitando-se a prioridade devida aos portadores de doença grave, em seguida, às pessoas com deficiência e, posteriormente aos idosos com 60 anos completos na data do pagamento. 
Essa interpretação, revela-se, a nosso sentir, compatível com os princípios e valores constitucionais, razão pela qual não se vê óbice algum a que tais situações sejam objeto de antecipação dos efeitos da tutela antecipada antecedente, com pagamento por meio do sistema de urgência no pagamento de obrigações oriundas da estabilização dos efeitos contra a Fazenda Pública, por revelar hipótese de concretização dos direitos humanos.

O procedimento das requisições de pequeno valor deve, inicialmente, seguir caminhos semelhantes a dos precatórios, iniciando com a requisição do juiz titular do feito para o Presidente do Tribunal a que estiver vinculado, para que este faça a expedição de oficio requisitório, contendo a decisão mandamental para que realize o pagamento imediatamente ou deposite os valores à disposição do Tribunal, conforme o procedimento adotado, resguardando o trâmite mínimo necessário para o processamento do pagamento, que para a União é de sessenta dias, art. 17, caput, da Lei no 10.259/2001 ${ }^{95}$,

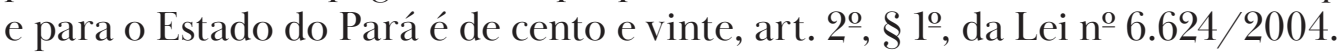

Deve-se observar que, enquanto no sistema de precatório as dotações orçamentárias e os créditos abertos são consignados diretamente ao Poder Judiciário, pois já é conhecido o credor, no sistema de cumprimento das obrigações de pequeno valor isso não pode ocorrer porque não há como saber o beneficiário da decisão judicial antecipadamente, como ocorre no sistema de precatório ${ }^{96}$.

No caso dos precatórios, primeiro há a habilitação por credor e somente depois a fixação da despesa pública; ao contrário, no caso dos débitos de pequeno valor, quando da previsão orçamentária, não é possível saber o valor exato das possíveis condenações enquadradas nessa espécie de execução contra a Fazenda Pública ${ }^{97}$.

Assim, a decisão tem natureza mandamental, devendo a administração providenciar o pagamento, depositar os numerários à disposição do Tribunal ou as alterações orçamentárias necessárias para que o pagamento seja efetuado, caso a dotação orçamentária da despesa pública para esse fim não seja suficiente ou, seja inexistente, sem prejuízo das consequências jurídicas inerentes ao descumprimento das decisões judiciais, inclusive de sequestro .

Diante do exposto, observa-se que a análise das prerrogativas processuais da Fazenda Pública - com base nos casos em que se permite a concessão de tutela antecipada contra a Fazenda Pública, na jurisprudência do STF, que tem restringido a aplicação da ADC n. 4, nas hipóteses da STA n.o 175 e nas exceções à remessa necessária, bem como no entendimento acerca do cabimento da ação monitória dá ensejo à estabilização dos efeitos da tutela provisória, permitindo a permanência desse mecanismo processual com a satisfação dos sujeitos com os efeitos da decisão estabilizada. A estabilização constitui, pois, uma importante ferramenta na concretização dos direitos sociais ${ }^{98}$.

Como resumo de cada ponto apresentado, observa-se a possibilidade de estabilização dos efeitos da tutela antecipada em caráter antecedente em várias hipóteses, começando pelas seguintes obrigações: fazer, não fazer e dar contra a Fazenda Pública, porque, para o cumprimento dessas obrigações, não há a exigência de atendimento ao sistema de precatório, embora algumas decisões possam influir indiretamente no orçamento público.

Ato contínuo, cabe destacar as exceções à ADC n.․ 4 e os seguintes precedentes do STF: a) Rcl 8.074/CE, que assegura a candidato aprovado em concurso a nomeação e a posse em cargo público; b) AgR na Rcl 3.483, para as demandas que não traduzem aumento pecuniário, mas representam mero

95 Art. 17. Tratando-se de obrigação de pagar quantia certa, após o trânsito em julgado da decisão, o pagamento será efetuado no prazo de sessenta dias, contados da entrega da requisição, por ordem do Juiz, à autoridade citada para a causa, na agência mais próxima da Caixa Econômica Federal ou do Banco do Brasil, independentemente de precatório.

96 SILVA, Sandoval Alves da. Aspectos orçamentários e constitucionais da requisição de pequeno valor - RPV. In: José Mauricio Conti, Fernando Facury Scafff. (Org.). Orçamentos Públicos e Direito Financeiro. led. São Paulo: Revista dos Tribunais, 2011, v. 1, p. 475.

97 SILVA, Sandoval Alves da. Direitos sociais: leis orçamentárias como instrumento de implementação. Curitiba: Juruá, 2007, p. 151.

98 SILVA, Sandoval Alves da; SILVA, Barbie Chaves. A estabilização dos efeitos da tutela antecipada contra a Fazenda Pública como instrumento de efetivação dos direitos sociais. Revista Brasileira de Direito Processual, Belo Horizonte, ano 28, n. 111, [jul./set. 2020]. No prelo. 
óbice judicial à redução de verba salarial; c) AgR na Rcl 6.468/SE, que versou sobre a reintegração de servidor no cargo ou posto, até julgamento da demanda, sem concessão de efeito financeiro pretérito; d) Súmula 729 do STF em matéria previdenciária, além de outras exceções julgadas pela Suprema Corte do país.

No que se refere à STA 175 (saúde), podem-se listar as questões relacionadas: a) ao fornecimento de prestação de saúde que não pertence ao quadro do SUS ou sem a prévia aprovação pela Administração Pública; b) ao custeio de prestações de saúde não abrangidas pelas políticas públicas; c) à disponibilização de medicamentos e tratamentos experimentais não registrados na Agencia Nacional de Vigilâncias Sanitária (Anvisa) ou não aconselhados pelo SUS etc., visto que o Poder Público não pode manter-se omisso ante os problemas ligados à saúde pública.

Em relação à remessa necessária, defende-se a estabilização dos efeitos da tutela antecipada antecedente nas seguintes hipóteses: a) causa de valor certo e líquido inferior a 1.000 (mil) saláriosmínimos para a União e as respectivas autarquias e fundações de direito público, a 500 (quinhentos) salários-mínimos para os Estados, o Distrito Federal, as respectivas autarquias e fundações de direito público e os Municípios que constituam capitais dos Estados, a 100 (cem) salários-mínimos para todos os demais Municípios e respectivas autarquias e fundações de direito público; b) sentença ou decisão fundada em: b.1) súmula de tribunal superior, b.2) acórdão proferido pelo STF ou pelo STJ em julgamento de recursos repetitivos, b.3) entendimento firmado em incidente de resolução de demandas repetitivas ou de assunção de competência e b.4) entendimento coincidente com orientação vinculante firmada no âmbito administrativo do próprio ente público, consolidada em manifestação, parecer ou súmula administrativa ${ }^{99}$.

Entretanto, para que o autor tenha sucesso na estabilização dos efeitos da tutela definitiva contra a Fazenda Pública, faz-se necessário o atendimento de alguns pontos para que deixe claro para o juiz o que pretende processualmente estabilizado, levando em consideração o elemento volitivo.

Nesse sentido, propõe-se que o autor adote as seguintes medidas: a) indique expressamente na petição inicial simplificada que pretende valer-se do que consta no artigo 304 do CPC; b) requeira prazo ampliado superior aos prazos de manifestação do Poder Público para alcançar os efeitos pretendidos, nos termos do inciso I do $§ 1 .^{\circ}$ do artigo 303 do CPC, sob pena de gerar confusão entre o prazo de emenda do autor e os prazos de impugnações a que se submete a decisão concessiva contra a Fazenda Pública, cabendo ao juiz conferir prazo para emenda superior aos prazos de recurso ou impugnação, permitindo a atuação resolutiva na crise de direito material; c) indicação na petição simplificada se a causa versa sobre matéria objeto de parecer ou súmula vinculante administrativa ou de teses ou precedentes vinculantes, se for o caso; d) desistência da emenda ou da ação, caso haja renúncia ou desistência do direito de recorrer ou impugnar.

\section{Conclusões}

Das razões aqui expostas, infere-se que as prerrogativas processuais concedidas à Fazenda Pública sustentam-se em virtude da necessidade de equilibrar a relação processual, com fundamento, supostamente, no princípio da supremacia do interesse público sobre o interesse privado e no princípio da indisponibilidade do interesse público, que norteiam todos os atos pertinentes ao Poder Público. Porém, há várias hipóteses em que se pode aplicar a concessão de liminares contra a Fazenda Pública e sua estabilização, consoante já se anuncia.

Um dos principais problemas enfrentados pelo Poder Público em juízo são as tutelas provisórias. Como forma de demonstrar teoricamente o tema, apesentou-se um profundo estudo das ações cautelares à luz do CPC de 1973 da lavra de Calmon de Passos, que faz uma contextualização do tema na Teoria Geral do Direito, na Teoria Geral do Processo, chegando à Teoria Geral do Processo da Cautelar,

99 Esse caso não é objeto do presente artigo, mas poderia até caber concessão de liminar por meio da tutela de evidência nos termos do artigo 311, II, do CPC. Isso não impede, porém, que seja utilizado o instrumento da estabilização dos efeitos da tutela definitiva concedida em caráter antecedente. 
de forma a conhecer o conjunto e a unidade, deduzindo os princípios e construindo a harmonia e a coerência sistêmica do instituto cautelar.

A apresentação dessa teoria é importante, principalmente porque o CPC unificou os institutos da tutela provisória de urgência - distinguindo cautelares e tutelas antecipadas - e de evidência, razão pela qual é possível perceber mais precisamente os institutos teoricamente. Mas, além disso, o CPC de 2105 trouxe a previsão da estabilização dos efeitos da tutela antecipada em caráter antecedente, visto que a estabilização surge como um instrumento processual capaz de garantir a celeridade e a efetividade da tutela jurisdicional sem resolução de mérito, atendendo a fruição do bem da vida, como diria Calmon de Passos, ainda mais quando se tratar da fruição dos direitos sociais.

O objeto deste estudo não foi restringido pela inovação trazida pelo CPC no que diz respeito à estabilização dos efeitos da tutela antecipada, conforme previsão no artigo 304 do CPC. De fato, adentrouse a defesa da aplicação do instituto contra a Fazenda Pública, mesmo diante de tantas prerrogativas do Poder Público em juízo, que parecem prima facie guardar forte incompatibilidade com sua aplicação, como prazo em dobro, remessa necessária etc.

Observa-se que a análise das prerrogativas processuais da Fazenda Pública - com base nos casos em que se permite a concessão de tutela antecipada contra a Fazenda Pública, na jurisprudência do STF, que tem restringido a aplicação da ADC n. 4, nas hipóteses da STA n.o 175 e nas exceções à remessa necessária, bem como no entendimento acerca do cabimento da ação monitória - dá ensejo à estabilização dos efeitos da tutela provisória, permitindo a permanência desse mecanismo processual com a satisfação dos sujeitos com os efeitos da decisão estabilizada. Constata-se, portanto, que a estabilização constitui uma importante ferramenta na concretização dos direitos sociais.

Para que isso ocorra, deve-se atender o elemento volitivo e também algumas sugestões, destacando-se as seguintes medidas: a) indicação expressa na petição inicial simplificada que se pretende valer do que consta no artigo 304 do CPC; b) requerimento de prazo ampliado superior aos prazos de manifestação do Poder Público para alcançar os efeitos pretendidos, nos termos do inciso I do $\$ 1 .^{\circ}$ do artigo 303 do CPC, sob pena de gerar confusão entre o prazo de emenda do autor e os prazos de impugnações a que se submete a decisão concessiva contra a Fazenda Pública, cabendo ao juiz conferir prazo para emenda superior aos prazos de recurso ou impugnação, permitindo a atuação resolutiva na crise de direito material; c) indicação na petição simplificada se a causa versa sobre matéria objeto de parecer ou súmula vinculante administrativa ou de teses ou precedentes vinculantes, se for o caso; d) desistência da emenda ou da ação, caso haja renúncia ou desistência do direito de recorrer ou impugnar.

Assim sendo, quando o deferimento de uma tutela provisória requerida em caráter antecedente mostra-se suficiente para resolver a problemática que envolve os sujeitos ou para acomodar seus interesses, a estabilização surge como um instrumento processual capaz de garantir a celeridade e a efetividade da tutela jurisdicional sem resolução de mérito, ainda mais quando se tratar da fruição dos direitos humanos, especialmente, os sociais.

\section{Referências}

AMARAL, Fernando Henrique de Abreu. A tutela provisória contra a Fazenda Pública no novo CPC. 2016. Trabalho de Conclusão de Curso (Graduação em Direito) - Universidade Federal do Rio Grande do Sul, Porto Alegre, 2016.

BERTAGNOLLI, Ilana. Judicialização do direito fundamental à saúde: uma análise do Ag. Reg. na Suspensão de Tutela Antecipada: STA n. 175-CE. Revista USCS - Direito, São Caetano do Sul, ano X, n. 20, p. 83-94, jan./jun. 2011.

BUENO, Cassio Scarpinella. O poder público em juízo: uma proposta de sistematização. Palestra proferida na IV Jornada de Direito Processual Civil. Fortaleza, 2001.

CÂMARA, Alexandre Freitas. O novo processo civil brasileiro. 3. ed. São Paulo: Atlas, 2017. 
CARDOSO, Luiz Eduardo Galvão Machado. Estabilização da tutela antecipada. 2017. 177 f.

Dissertação (Mestrado em Direito) - Universidade Federal da Bahia, Salvador, 2017.

CASTRO, Thaise Braga. Tutela provisória: tutela da urgência e a estabilização da demanda. Revista Jurídica da Procuradoria-Geral do Distrito Federal, Brasília, DF, v. 40, n. 2, p. 13-30, jul./dez. 2015 .

CUNHA, Leonardo Carneiro da. A Fazenda Pública em juízo. 14. ed. Rio de Janeiro: Forense, 2017.

CUNHA, Leonardo Carneiro da. A Fazenda Pública em juízo. 15. ed. rev. atual. e ampl. Rio de Janeiro: Forense, 2018.

DIAS, Licínia Rossi Correia. Direito administrativo I. São Paulo: Saraiva, 2012. (Saberes do Direito, 31).

DIDIER JR., Fredie. Curso de direito processual civil. Salvador: JusPodivm, 2015.

DIDIER JR., Fredie; BRAGA, Paula Sarno; OLIVEIRA, Rafael Alexandria de. Curso de direito processual: teoria da prova, direito probatório, decisão, precedente, coisa julgada e tutela provisória. 12. ed. Salvador: JusPodivm, 2017.

GRECO, Leonardo. Instituições de processo civil: processo de conhecimento. 3. ed. Rio de Janeiro: Forense, 2011.

GRECO, Leonardo. A tutela da urgência e a tutela da evidência no Código de Processo Civil de 2015. In: MACÊDO, Lucas Buril de; PEIXOTO, Ravi; FREIRE, Alexandre (org.). Procedimentos especiais, tutela provisória e direito transitório. 2. ed. Salvador: JusPodivm, 2016. p. 185-208. (Coleção Novo CPC, Doutrina Selecionada, 4).

MAGALHÃES, Breno Baía; SILVA, Sandoval Alves da. O grau de vinculação dos precedentes à luz do STF: o efeito vinculante é absoluto? Revista de Informação Legislativa, Brasília, DF, v. 49, n. 195, p. 77-96, jul./set. 2012.

NUNES, Dierle; ANDRADE, Érico. Os contornos da estabilização da tutela provisória de urgência antecipatória no Novo CPC e o mistério da ausência de formação da coisa julgada. In: MACÊDO, Lucas Buril de; PEIXOTO, Ravi FREIRE, Alexandre (org.). Procedimentos especiais, tutela provisória e direito transitório. 2. ed. Salvador: JusPodivm, 2016. cap. 3, p. 69102. (Coleção Novo CPC, Doutrina Selecionada, 4).

PASSOS, José Joaquim Calmon de. Ações cautelares. Revista da Faculdade de Direito da UFPR, Curitiba, v. 21, n.․ 0, p. 29-62, 1983. Disponível em: https://revistas.ufpr.br/direito/article/ view/8872/6185. Acesso: 9 jul. 2020.

RIBEIRO, Leonardo Ferres da Silva. Tutela provisória (evolução e teoria geral). In: CAMPILONGO, Celso Fernandes; GONZAGA, Alvaro de Azevedo; FREIRE, André Luiz (coord.). Enciclopédia jurídica da PUCSP. São Paulo: Pontifícia Universidade Católica de São Paulo, 2017. Tomo: Processo Civil. Disponível em: https://enciclopediajuridica.pucsp.br/verbete/166/edicao-1/ tutela-provisoria-\%28evolucao-e-teoria-geral\%29. Acesso em: 24 out. 2018.

RISSO, Edimara Sachet; BUZETTI, Jorge Augusto. A possibilidade de deferimento da tutela antecipada em face da Fazenda Pública. Revista Faz Ciência, [s.l.], v. 11, n. 14, p. 11-38, jul./dez. 2009.

SCALABRIN, Felipe; SANTANNA, Gustavo. Perfil da remessa necessária no novo Código de Processo Civil. Revista da AJURIS, Porto Alegre, v. 42, n. 137, p. 303-320, mar. 2015.

SCARPELLI, Natália Cançado. Estabilização da tutela provisória de urgência antecipada requerida em caráter antecedente. 2016. 186 f. Dissertação (Mestrado em Direito Processual Civil) Pontifícia Universidade Católica de São Paulo, São Paulo, 2016.

SICA, Heitor Vitor Mendonça. Doze problemas e onze soluções quanto à chamada "estabilização da tutela antecipada”. Revista do Ministério Público do Rio de Janeiro, Rio de Janeiro, n. 55, p. 85-102, jan./mar. 2015. 
SILVA, Marcus Vinicius Fernandes Andrade. Precatórios judiciais e requisições de pequeno valor: algumas considerações. Âmbito Jurídico, Rio Grande, ano XIII, n. 74, mar. 2010. Disponível em: http://www.ambito-juridico.com.br/site/index.php?n_link=revista_artigos_leitura\&artigo_ $\mathrm{id}=7286$. Acesso em: 12 nov. 2018.

SILVA, Sandoval Alves da. Direitos sociais: leis orçamentárias como instrumento de implementação. Curitiba: Juruá, 2007.

SILVA, Sandoval Alves da. Aspectos orçamentários e constitucionais da requisição de pequeno valor RPV. In: José Mauricio Conti, Fernando Facury Scafff. (Org.). Orçamentos Públicos e Direito Financeiro. 1ed. São Paulo: Revista Dos Tribunais, 2011, v. 1, p. 461-489.

SILVA, Sandoval Alves da. O Ministério Público e a concretização dos direitos humanos. Salvador: JusPodivm, 2016a.

SILVA, Sandoval Alves da. Aula 4: Estabilização dos efeitos da tutela provisória. Videoaula 2016: Novo Código de Processo Civil. Dez. 2016b. 1 vídeo (17 min). Disponível em: https://www.youtube. com/watch?v=pisbjvCCydM\&t=308s. Acesso em: 3 nov. 2018.

SILVA, Sandoval Alves da; SILVA, Barbie Chaves. A estabilização dos efeitos da tutela antecipada contra a Fazenda Pública como instrumento de efetivação dos direitos sociais. Revista Brasileira de Direito Processual, Belo Horizonte, ano 28, n. 111, [jul./set. 2020]. No prelo.

VALIM, Pedro Losa Loureiro. A estabilização da tutela antecipada. Revista Eletrônica de Direito Processual, Rio de Janeiro, v. 16, n. 16, p. 478-505, jul./dez. 2015.

VALIM, Pedro Losa Loureiro. Référé francês e o instituto da estabilização da tutela antecipada. Revista Jus Navigandi, Teresina, ano 22, n. 5216, 12 out. 2017. Disponível em: https://jus.com. br/artigos/60593. Acesso em: 22 out. 2018.

VALLE, Gustavo Henrique Moreira do; CAMARGO, João Marcos Pires. A audiência pública sobre a judicialização da saúde e seus reflexos na jurisprudência do Supremo Tribunal Federal. Revista de Direito Sanitário, São Paulo, v. 11, n. 3, p. 13-31, fev. 2011.

VENTURI, Elton. Transação de direitos indisponíveis? Revista de Processo, São Paulo, v. 41, n. 251, p. 391-426, jan. 2016. 